\title{
I. EDUCATIONAL ROBOTICS IN PRIMARY SCHOOL: UNUSUAL METHODS OF EVALUATION
}

\author{
Karolína MAYEROVÁ-Michaela VESELOVSKÁ
}

\begin{abstract}
In this article we offer brief overview of evaluation, assessment process and importance of functions, which should support evaluation. Further, look at the article from the perspective of educational robotics and we are trying to find appropriate evaluation methods that could make lessons with educational robotics more effective. Reasons for choosing unusual methods of evaluation robotics lessons are described in detail in article. In the same way we describe how have we designed and created these methods, their implementation and analysis of data that were collected during testing. At the end we confirm some conclusions using the interview with the class teacher and teacher who teachers educational informatics. Research we are describing in this article is very closely linked to our previous research and builds on the results of our previous research, which is part of the dissertation.
\end{abstract}

Key words: primary school, educational robotics, evaluation.

\section{EDUKAČNÁ ROBOTIKA NA PRVOM STUPNI ZÁKLADNÝCH ŠKÔL: NETRADIČNÉ METÓDY HODNOTENIA}

\begin{abstract}
Abstrakt: V tomto článku ponúkame stručný pohl'ad na hodnotenie, jeho procesy a dôležitost' funkcií, ktoré má hodnotenie podporovat'. Ďalej sa v článku pozeráme na hodnotenie z pohl'adu edukačnej robotiky a snažíme sa nájst' vhodné hodnotiace metódy, ktoré by zefektívnili proces výučby pri používaní robotických stavebníc na vyučovaní. V článku podrobne popisujeme dôvody, prečo sme si vybrali práve netradičné metódy hodnotenia aktivít, ktoré so žiakmi robíme. Podrobne popisujeme aj priebeh návrhu a tvorby týchto metód, ich implementáciu a analýzu na základe zozbieraných údajov počas testovania. V závere článku ponúkame zdôvodnenia niektorých zistení, podporené aj tvrdeniami od triednej pani učitel'ky a od učitel'ky učiacej túto triedu informatickú výchovu. Popisovaný výskum priamo súvisí a nadväzuje aj na výsledky nášho doterajšieho výskumu, ktorý je súčastou dizertačnej práce.
\end{abstract}

Kl'účové slová: prvý stupeň ZŠ, edukačná robotika, hodnotenie.

\section{1 Úvod}

$\mathrm{V}$ posledných rokoch je čoraz modernejšie použivat' roboty a robotické stavebnice na vyučovaní. Podl'a dostupných materiálov sa najčastejšie používajú robotické stavebnice LEGO Mindstorms [1], [2], [3] a [4]. Tento trend začal na vysokých školách a postupne sa zavádza aj do nižších stupňov škôl. Na prvom stupni je stále takáto výučba vel'mi ojedinelá a aj preto je vel'mi náročné nájst' relevantné materiály, ktoré by hovorili o vhodnom používaní robotických stavebníc na vyučovacích hodinách. Jeden z mála dostupných dokumentov, ktorý hovorí o konkrétnych aktivitách s čiastkovými ciel'mi, návrhoch hodnotení týchto aktivít a obsahuje aj pripravené materiály $\mathrm{k}$ týmto aktivitám, je napríklad kurikulum [5] z americkej školy v New Yorku. Ten je však v podstate vel'mi nový a nerozšírený. Okrem nedostatku relevantných materiálov, stretli sme sa v našom výskume aj s inými problémami ako sú napríklad: vysoké ceny robotov, malá časová dotácia predmetu, problematické hodnotenie tímovej spolupráce a mnohé iné. Faktory spôsobujúce tieto problémy vzájomne súvisia a navzájom sa mnohokrát ovplyvňujú. Napríklad vysoká cena stavebníc spôsobuje, že škola nemá pre každého žiaka vlastnú stavebnicu. Preto žiaci väčšinou pracujú $\mathrm{v}$ tímoch zložených z dvoch alebo troch členov. Takáto spolupráca síce môže mat' aj svoje výhody ako napríklad rozvoj kooperácie, kolaborácie, komunikácie, sociálnych zručností a mnohých iných zručností, ktoré sú potrebné nie len pre d’alšie štúdiu, ale aj pre budúce zamestnanie [5], [6], [7]. Na druhej strane tu však vzniká problém, ako takúto spoluprácu spravodlivo ohodnotit'. Učitel', ktorý má v triede tri až štyri tímy, nie je schopný v priebehu hodiny sledovat', či všetci žiaci v tíme pracujú aktívne alebo nie. Preto sme sa snažili do vyučovania 
edukačnej robotiky zaviest' vhodné a možno netradičné metódy hodnotenia. Zamerali sme sa na viaceré funkcie týchto metód hodnotenia.

Výskum je súčast’ou širšej dizertačnej práce. Všetky nami navrhnuté aktivity (bez hodnotenia) boli testované v predošlých etapách výskumu, ale spôsoby hodnotenia neboli doteraz do výskumu zahrnuté. Návrh a implementácia netradičných spôsobov hodnotenia sú d'alšou iteráciou v procese nášho výskumu.

\section{Použité výskumné metódy}

Výskum, ktorý robíme s robotickými stavebnicami na základných školách je časovo náročný. Len málo škôl má zakúpené robotické stavebnice, a preto si do škôl nosíme vlastné stavebnice, s ktorými žiaci pracujú na hodinách. Z tohto dôvodu nemôže výskum prebiehat' súčasne na viacerých školách.

Jedným z dôvodov, prečo sme nezvolili kvantitatívny výskum je, že potenciálna výskumná vzorka je vel'mi malá na to, aby poskytla zovšeobecnitel'né a objektívne výsledky.

V tomto článku sa venujeme hodnoteniu, pričom testujeme netradičné spôsoby hodnotenia, ktoré nie sú bežne používané vo vyučovaní na slovenských školách. Na väčšine slovenských škôl sa práca žiakov hodnotí známkami. Len školy, ktoré požiadali štát o povolenie, môžu hodnotit' svojich žiakov slovne. Výber našej výskumnej vzorky sme volili tak, aby žiaci zapojení do tohto testovania boli na netradičné spôsoby výučby a hodnotenia zvyknutí. Preto sme si vybrali žiakov zo súkromnej základnej školy, kde žiaci dostávajú slovné hodnotenie a nie známky. Sú v neustálom styku s podobnými netradičnými metódami, aké chceme zaviest' do edukačnej robotiky. Takto sme chceli docielit' vyššiu výpovednú hodnotu výskumu.

Ked'že zámerom tejto štúdie bolo overenie nami navrhnutých metód, vybrali sme si pre náš výskum ako dizajn výskumu prípadovú štúdiu [8]. Našou výskumnou vzorkou boli žiaci druhého ročníka $z$ triedy prvého stupňa ZŠ, rozdelení na dve skupiny. Pre väčšiu validitu výsledkov sme používali viaceré dostupné spôsoby zbierania dát, ktoré umožňuje prípadová štúdia. Okrem terénnych zápiskov sme všetky vyučovacie hodiny zaznamenávali na kameru, fotografovali, robili rozhovor striednou učitel'kou a učitel'kou informatickej výchovy. Súčast'ou metódy hodnotenia boli aj krátke dotazníky s otvorenými otázkami, ktoré žiaci vypĺn̆ali na hodinách. Odpovede, ktoré žiaci uvádzali v dotazníkoch sme analyzovali a snažili sa nájst' tvrdenia, resp. teóriu, ktorou by sme vedeli popísat' získané dáta. Namiesto toho sa nám analýzou dát zväčšil okruh otázok, na ktoré sme potrebovali získat' odpoved'. Na základe rozhovoru s triednou učitel'kou, ktorá nám vysvetlila charakter a povahu chovania žiakov, sa okruh týchto otázok zúžil a začali sa rysovat' prvé opisné teórie. Po získaní týchto prídavných informácií sme sa mohli zamerat' na zodpovedanie otázok, ktorých odpovede smerovali priamo k ciel'om nášho výskumu.

Samozrejme vol'ba výskumnej metódy bola ovplyvnená výskumnými otázkami, ktoré jasne určovali ciel' výskumu. Výskumné otázky:

1. Ako reagujú deti pri zavádzaní nami navrhnutých hodnotiacich metód do vyučovania?

2. Aké dôvody a argumenty uvádzajú deti na obhajobu svojich názorov? Aký je potenciál pre rozvoj ich argumentačných schopností?

\section{Teoretické východiská}

Podl'a nášho doterajšieho prieskumu neexistuje vel'a relevantných materiálov, ktoré by hovorili o overenej metodike a aktivitách, ako využit' stavebnicu LEGO WeDo s det'mi na prvom stupni Z $\breve{S}$ (6 - 11 rokov). Väčšina prác, ktoré sa venujú edukačnej robotike sú určené pre staršie deti a na mimoškolské aktivity, napr.: [9], [10]. „A Currriculum Unit on Programming and Robotics“ [5] je jedným z mála metodických materiálov pre robotiku na prvom stupni ZŠ. Toto kurikulum navrhla Amandou Sullivan s výskumným tímom pre americkú základnú školu v New Yorku. V dokumente je uvedený zoznam aktivít, ktoré si učitelia môžu rozvrhnút' na rôzne dlhé časové obdobie. Jasne sú však vytýčené ciele, ktoré jednotlivé aktivity sledujú a konkrétny návrh hodnotenia týchto aktivít. Návrh aktivít je dobre premyslený a sleduje nárast vedomostí žiaka pracujúceho s robotickou stavebnicou. Avšak použitie takéhoto charakteru hodnotenia nám po prvé, neumožňuje fakt, že v našom výskume nemá každý študent svoju stavebnicu a po druhé, takýto spôsob hodnotenia je podobný tradičnému známkovaciemu systému, ktorým učitelia hodnotia žiakov, len je v ňom vidiet' snahu o väčšiu objektívnost'.

Podl'a J. Slavíka z knihy [11], školské hodnotenie v sebe zahrn̆uje všetky hodnotiace procesy a ich prejavy, ktoré bezprostredne ovplyvňujú školskú výučbu alebo o nej nejakým spôsobom hovoria. Podl'a Tureka [12] by malo byt' takéto hodnotenie viac kontrolované a premyslené, pretože na základe kontroly a z nej 
vyplývajúceho hodnotenia a klasifikácie sa rozhoduje o d'alšom osude žiakov (vol'ba povolania, prijatie na vysokú školu, ...), čím zasahuje najcitlivejšiu sféru človeka - jeho sebavedomie.

Takáto kontrola vyučovacieho procesu sa skladá z dvoch procesov, a síce, zo zist'ovania a z posúdenia výsledkov vyučovacieho procesu [12]. Tieto dva procesy sa nielenže zdajú vel'mi podobné, ale reálne sú aj vzájomne vel'mi prepojené.

- Pri zist'ovaní výsledkov vyučovacieho procesu ide $\mathrm{v}$ podstate o meranie výkonu žiakov, o zistenie toho, čo vedia a čo nie, aká je miera poznatkov v porovnaní s tým, čo vediet' majú a v čom sa každý ako jednotlivec zlepšil. Túto činnost' môžeme nazývat’ aj preverovanie, či skúšanie.

- Posúdenie výsledkov vyučovacieho procesu, inak povedané - hodnotenie, je pripisovanie hodnoty tým, kto hodnotí (zvyčajne učitel'om), tomu, koho alebo čo hodnotí (t.j. zvyčajne žiakovi alebo jeho výkonu).

$\mathrm{Na}$ Slovensku sa hodnotenie žiakov zvykne vyjadrovat' vo forme čísla, resp. známky. Takémuto hodnoteniu hovoríme klasifikácia, t.j. zarad'ovanie žiakov do výkonnostných skupín, ktorých máme na Slovensku 5. Ako synonymum sa často používa aj výraz známkovanie, čo nie je podl'a Tureka úplne adekvátne, pretože jednotlivé výkonnostné skupiny nemusia byt' hodnotené len známkami, ale aj písmenami (napr.: A, B, C, D, E) alebo slovným hodnotením.

Pri kontrole vyučovacieho procesu by sa nemal dávat' dôraz len na jednu funkciu tohto procesu (kontrolnú), ako to možno často vidiet' na vyučovaní, ale na všetky jeho funkcie (prognostická, motivačná, výchovná, informačná, rozvijajúca či spätnoväzobná). Podceňovanie napríklad spätnoväzobnej či motivačnej funkcie vedie $\mathrm{k}$ tomu, že žiaci sa stavajú ku klasifikácií odmietavo až záporne a vôbec ju nepokladajú za niečo, čo im môže pomôct' k lepšiemu zvládaniu preberanej látky. Tradičné známkovanie ako ho poznáme zo škôl, podporuje len niektoré funkcie, väčšinu $z$ nich skoro vôbec. Aj preto chceme $v$ našich návrhoch hodnotenia rozvíjat' tie funkcie, ktoré sú menej podporované, napr. motivačnú, rozvíjajúcu, spätnoväzobnú a výchovnú. Tie majú podl'a [12] za úlohu:

1. Motivačná: udržiavanie a zvyšovanie štúdijnej aktivity žiakov,

2. Rozvíjajúca: rozvoj schopnosti sebakontroly a sebahodnotenia žiakov,
3. Spätnoväzobná: získavanie informácií o úspešnosti vyučovacieho procesu žiakmi a učitel'om na reguláciu d'alšieho postupu tak, aby sa efektívne dosiahli ciele vyučovacieho procesu,

4. Výchovná: formovanie pozitívnych vlastností a postojov a odstraňovanie negatívnych vlastností.

Ako bolo spomenuté vo výskumných metódach, pre náš výskum bolo dôležité, aby deti, ktoré budú testované nami navrhnutými hodnotiacimi metódami, boli zvyknuté na netradičné spôsoby a metódy hodnotenia. Najlepšie na tie, ktoré by už v minulosti rozvíjali viaceré funkcie hodnotenia. Napríklad slovné hodnotenie. Preto ideálnou vol'bou bola súkromná základná škola $\mathrm{v}$ Bratislave, ktorá hodnotí svojich žiakov slovným hodnotením.

\section{Priebeh výskumu}

Výskum prebiehal na súkromnej základnej škole pre nadané deti. Výskumu sa zúčastnila jedna trieda druhákov rozdelená na dve skupiny, ktoré mali informatickú výchovu vo štvrtok ráno hned' za sebou - prvú a druhú vyučovaciu hodinu. $\mathrm{V}$ prvej skupine bolo 8 žiakov (5 dievčat a 3 chlapci). V druhej skupine bolo 7 žiakov (3 dievčatá a 4 chlapci). Mená žiakov sme pre potreby výskumnej správy zmenili.

$\mathrm{Na}$ prvej hodine sa žiaci sami rozdelili do tímov, v ktorých pracovali aj na d'alších hodinách. Zmeny v tímoch nastali, len ak niekto chýbal, alebo ak to vyžadovali potreby výskumu. Výskum prebiehal počas piatich hodín $\mathrm{v}$ oboch triedach paralelne. Prvé štyri hodiny odučil jeden člen výskumného tímu a poslednú hodinu odučila ich učitel'ka informatickej výchovy. Pred začatím hodiny jej boli povedané inštrukcie, ako majú byt' odučené aktivity danej hodiny. Druhý člen výskumného tímu vždy zaznamenával priebeh hodiny, t.j. robil terénne poznámky, videá a fotografie.

Stručný opis priebehu piatich hodín, ktoré sme odučili:

- 1. hodina: Na začiatku hodiny sme urobili so žiakmi asi 10 - 15 minútový rozhovor o tom, čo je podl'a nich robot, kde sa s ním stretli, ako ho doteraz vnímali, atd'. Následne si mohli zo stavebnice LEGO WeDo postavit' svoj vlastný model robota a rozhýbat' ho pomocou motora, ktorý bol pripojený $\mathrm{k}$ PC.

- 2. hodina: Žiaci postavili podla návodu model lietadla, ktorý mali rozhýbat' troma rôznymi spôsobmi. Na domácu úlohu si 
mali rozmysliet', aký kolotoč si chcú postavit' na d'alšej hodine.

- 3. hodina: $\mathrm{Na}$ začiatku hodiny dostali zadanie, aby postavili kolotoč. Na konci hodiny mala každá skupina prezentovat' svoj model - ako sa volá, čo robí, čím je charakteristický, kol'ko l'udí odvezie, ... .

- 4. hodina: Táto hodina bola zameraná na tímovú spoluprácu a celá bola tematicky spojená príbehom o ,plt'ke“. Na začiatku sa rozprávalo o tom, čo je to plt’ka, či sa s ňou niekto stretol, atd'. Následne sa žiaci rozdelili do trochu väčších skupín. Každá skupina si vybrala jedného zástupcu, ktorý sa mohol chodit' pozerat' na skryté modely, ktoré sme vopred pripravili. Potom ich musel ostaným členom skupiny opísat' len slovne, bez používania rúk, či inej časti tela a na základe tohto popisu mali žiaci daný model postavat'. Pri každom d'alšom kole sa menil opisovaný model aj člen, ktorý model opisoval. Takto sa mohli vystriedat' všetci členovia tímu. Modely boli koncipované od najjednoduchších až po zložité (napr. prevod dvoch ozubených kolies).

- 5. hodina: Učitel'ka žiakov najprv oboznámila s úlohou postavit' model lode, ktorá nezastavila na hranici, ale stihli ju zachytit' bezpečnostné kamery. Úlohou žiakov bolo postavit' model lode zo stavebnice podl'a troch fotografií, ktoré dostali. Okrem fotografíi dostali vytlačenú aj mapu so znázornenou trasou lode. Pomocou programu mali nasimulovat' pohyb lode, ako sa pohybovala po mape.

Prvé dve hodiny sa žiaci oboznamovali so stavebnicou a softvérovým prostredím. Až na tretiu a štvrtú hodinu sme zaradili naše navrhnuté metódy hodnotenia. Tieto metódy sme navrhovali a dotvárali spolu s učitel'kou, ktorá túto triedu učí informatickú výchovu - je dobre oboznámená s metódami, ktoré táto škola používa a zároveň dobre pozná vedomostný stav žiakov. Výsledkom našich rozhovorov bol návrh troch metód, ktoré majú rozvíjat' u žiakov vytváranie, formulovanie a prezentovanie vlastných, objektivnych a spravodlivých názorov na svoju prácu a na prácu a produkty vytvorené spolužiakmi. Prvé dve navrhnuté metódy sú si po obsahovej stránke vel'mi podobné a líšia sa len formou. Preto sme sa rozhodli skúsit' ich implementovat' na tretej vyučovacej hodine, v oboch skupinách paralelne.

Tretia metóda mala za úlohu prebudit' u žiakov záujem rozmýšl'at' o efektívnosti zloženia skupiny, o tímovej spolupráci, o hodnotení vlastností spolužiakov v súvislosti so strategickým plánovaním, vo forme zodpovedajúcej ich veku. Túto metódu sme zaradili na koniec štvrtej vyučovacej hodiny, lebo žiaci mali počas nej možnost' skúsit' si tímovú spoluprácu v inom zložení ako na predošlých hodinách. Mali teda možnost' porovnávat' viaceré výhody a nevýhody, ktoré priniesli noví členovia. Túto metódu sme implementovali rovnako $\mathrm{v}$ oboch skupinách. Stručný opis nami navrhovaných metód hodnotenia:

\section{Metóda1:}

$\mathrm{Na}$ konci hodiny dostali žiaci do triedy tabul'ku, kde boli v riadkoch napísané ich mená a v stĺpcoch boli názvy kolotočov, ktoré robili, spolu s vytlačenými obrázkami kolotočov. Do d’alšej hodiny mal každý za úlohu ku každému kolotoču napísat', čo si o ňom myslí.

Metóda2:

$\mathrm{Na}$ konci tretej hodiny žiaci dostali papier s vytlačenou tabul'kou, kde mali odpovedat' na tri zadania, ktoré zneli:

- Tvoje meno:

- Názov kolotoča, ktorý sa ti páči:

- Prečo sa ti páči:

\section{Metóda3:}

$\mathrm{Na}$ konci hodiny dostali žiaci papier s vytlačenou tabul'kou, kde mali odpovedat' na štyri otázky, ktoré zneli:

- S kým si bol/a v skupine dnes?

- S kým by si chcel/a byt nabudúce?

- Prečo?

- Ako sa ti dnes stavalo?

Po odučení hodín sme spravili analýzu zozbieraných dát, z ktorých nám vzišli rôzne otázky. Niektoré z nich sa nám zdali byt' l'ahko zodpovedatel'né osobou, ktorá by poznala charakter a vlastnosti žiakov. Preto sme robili rozhovor s triednou pani učitel'kou. O aktivitách a nami implementovaných metódach vedela dopredu a bola požiadaná, aby sledovala reakcie žiakov pri vyplńaní tabul'ky z Metódy1. Otázky, ktoré sme sa jej pýtali zneli:

1. Je pre žiakov takáto aktivita intelektuálne náročná? Alebo je pre nich bežná a teda stretli sa s podobnou aktivitou aj na iných hodinách?

2. Myslíte si, že takáto metóda je vhodným nástrojom pre žiakov na rozvoj ich argumentačných schopností?

3. Pýtali sa žiaci pri vyplńnaní tabul'ky čo majú robit', čo od nich chceme? Bolo ich treba vyzývat' $\mathrm{k}$ tomu, aby ju vyplnili? 
4. V akom poradí vypíňali tabul'ku? Mohla vzniknút' nejaká závislost' medzi odpoved'ami a poradím, vakom tabul'ku daný žiak vypĺ́ñal?

5. Prečo sú odpovede žiakov v štvrtom stĺpci tabul'ky, ktorú sme použili pri Metódel takmer totožné?

6. Čím mohli byt' spôsobené extrémne krátke odpovede žiakov v Metóde2?

7. Danka ako jediná osoba pri zdôvodňovaní svojich odpovedí uvádzala viacero argumentov. Cím to mohlo byt' spôsobené?

8. Pri Metóde3, kde sa mali žiaci vyjadrit', s kým by chceli byt' v skupine na budúcej hodine, nikto nenapísal Otku. Čím to mohlo byt' spôsobené?

9. Naopak vel'a žiakov chcelo byt' s Tomom, čím to mohlo byt' spôsobené?

10. Žiaci nepísali žiadne negatívne vyjadrenia. Mohlo to byt' spôsobené neúprimnost'ou, hanblivost'ou alebo neuvedomovaním si nedostatkov daného modelu, ktorý hodnotili?

\section{Výsledky výskumu}

Použitím troch metód, ktoré uvádzame v kapitole Priebeh výskumu, sme naplńali najmä výchovné a rozvíjajúce funkcie hodnotenia.

Ďalšie funkcie ako spätnoväzobná, je zabezpečená počas celého priebehu výučby edukačnej robotiky. Z doterajšieho pozorovania vieme, že žiaci majú vel'kú potrebu ukazovat' svoje poznatky - čiastkové objavy. Či už učitel'om, spolužiakom v tíme, alebo iným tímom, hoci aj na opačnej strane triedy. Tento jav je jasne pozorovatel'ný. Žiaci mnohokrát až kričia, kým k ním vyučujúci nepríde a nepochváli ich, resp. neschváli im aktuálny model. Tu možno jasne vidiet', ako je pre žiakov potrebné nielen hodnotenie výsledku, ale aj priebehu. Edukačná robotika toto umožňuje vel’mi prirodzeným spôsobom. Takéto ukazovanie a predvádzanie objavov býva zväčša hlasné, ale môže byt' aj tiché. Avšak vždy jasne upozorní zvyšné tímy, vakom štádiu je ich model v porovnaní s ukazovaným modelom spolužiakov. Zaznamenali sme viaceré prípady, ked' žiaci po takomto priebežnom predvedení modelu boli povzbudení, ako vel'mi sú popredu a začali sa snažit' ešte viac, aby skončili stavanie ako prví. Iní zas zistili, že sú vel'mi pozadu so stavaním, lebo značný čas strávili rozhovorom o farbe kocky a usúdili, že tento problém je zanedbatel'ný a začali naozaj postupovat'. Týmto spôsobom sa naozaj prirodzene spíňa motivačná funkcia, ako ju uvádzame v kapitole o teoretických východiskách.

Zavedením metód, ktoré podporujú tieto funkcie sme žiakov nenásilnou formou nútili zamýšl'at' sa nad formuláciou svojich dojmov a pocitov. Žiaci zároveň riešili problém objektívnosti medzi pravdou o modeli a tým, že autor modelu je ich kamarát.

\section{Analýza dát: prvá výskumná otázka}

Analýzou reakcií detí sme sa snažili nájst' odpoved’ na prvú výskumnú otázku: Ako reagujú deti pri zavádzaní nami navrhnutých hodnotiacich metód do vyučovania? Odpovede sme hl'adali analýzou videozáznamov. Chovanie žiakov pri požiadavke zodpovedania otázok Metódy 2 a 3 boli porovnatel'né s ich chovaním pri zadávaní úloh na začiatku hodiny, t.j. nespozorovali sme žiadne významné rozdiely vich správaní. Tieto metódy boli implementované až v závere vyučovania. Badatel'ná bola väčšia ochota dievčat, než chlapcov zanechat' prácu s LEGOm a pracovat' s papierom, na ktorom boli zadania úloh.

Ďalší fakt, na ktorý nás upozornila učitel'ka informatiky už pri prvotnom rozhovore, je vel'ký rozdiel medzi druhákmi a tretiakmi v čítaní a písaní. Túto skutočnost' sme naozaj následne mohli vidiet' aj v rozhovoroch, ktoré boli zaznamenané na videách. Ako ukážku uvádzame dva druhácke rozhovory, ktoré potvrdzujú ich oprávnené nedostatky v oblasti gramatiky.

Prvý rozhovor bol medzi dvoma dievčatami. Sonička nepochopila znenie poslednej otázky a nevedela, či na konci každej odpovede má dávat' bodky, tak sa pýtala Danky. Väčšina žiakov bodky na konci odpovedí nedávala.

Prepis ukážky:

Soňa: Ja nechápem to posledné. (Význam tretej otázky, ktorá bola napísaná na papieri.)

Danka: Ako sa ti dneska stavalo?

Soňa: Jáááj. Ahá.

Soňa: Za každým máme dat' bodku?

Danka: Asi hej.

Druhý rozhovor bol medzi dvoma chlapcami - Milom a Vilom. Milo mal potrebu zdiel'at' nahlas, čo chce napísat' do odpovede, avšak Vilo sa napriek tomu nenechal ovplyvnit' a ako jediný $\mathrm{z}$ triedy na otázku ako sa mu dnes pracovalo napísal „stredne“. Všetci ostatní žiaci napísali „dobre“, alebo „velmi dobre“. Ďalej sa Vilo, dovtedy inak výrazná postava, pýtal nezrozumitel’ným spôsobom na ý-čka v slove dobrý. 


\section{Prepis ukážky:}

Milo: Ja napíšem vel'mi dobre.

Vilo: Áno, dobrý je krátko. ... Dobrý je tiež s tvrdým (a pozerá spolužiakovi vedl'a neho do papiera).

Okrem problému s gramatikou ${ }^{5}$ a čítaním s porozumením, sme na videách zaznamenali aj vzájomné znemožňovanie odpisovania. Takéto chovanie žiakov nenarušovalo funkcie hodnotenia, ktoré sme chceli rozvíjat'. Plynulé a prirodzené plnenie úloh bez otázok umožnil aj fakt, že žiaci sú zvyknutí na hodnotenie svojich prác. Toto nám potvrdila aj učitel'ka informatiky pri prípravnom rozhovore. Vysvetlila nám, že žiaci dostávajú od učitel'ov na konci každého štvrt'roku, t.j. štyrikrát do roka, slovné hodnotenia o sebe, svojej práci, o pokrokoch ktoré robia, prípadne, ktoré by mali ešte spravit'. Na konci každého polroka, teda dvakrát za rok, si píšu aj oni sami na seba posudky. Z toho je zrejmé, že žiaci majú skúsenosti s formuláciou svojich tvrdení a s ich zdôvodňovaním.

\section{Analýza dát: druhá výskumná otázka}

Znenie druhej výskumnej otázky je: Aké dôvody a argumenty uvádzajú deti na obhajobu svojich názorov? Aký je potenciál rozvíjat' ich argumentačné schopnosti? Odpovede na tieto otázky sme hladali $\mathrm{v}$ odpovediach žiakov a následne $\mathrm{v}$ rozhovore s triednou pani učitel'kou. Vel'mi zaujímavé bolo, že všetky odpovede žiakov v Metódel boli pozitívne. Žiaci neuvádzali negatívne argumenty. Najnegatívnejšie odpovede zneli: „Páčil bi sa mi viac, keby ти nepadala vrtul'a.“, „Páćil sa mi. Len mu trochu odpadávala vrtul'a." Dalej to bola vel'mi podobná formulácia viet: „Páćil sa mi lebo ...", „Páćil sa mi preto lebo...", „Mne sa páćil lebo ...", „Tento kolotoč sa mi páćil lebo ...“, ... . Zdôvodnenie tohto zistenia sme hl'adali v odpovedi učitel'ky (otázka č.10), kde vravela, že žiaci vedia byt' naozaj kritický, ak si to myslia. To, že neuvádzali negatívne názory znamená, že sa im modely naozaj páčili. $Z$ tejto pre nás významnej informácie vyplýva, že žiakom sa práca s LEGOm naozaj páčila, aj ked' na pútavé aktivity počas výučby sú zvyknutí. Toto zistenie nám potvrdili aj pri osobnom rozhovore na konci hodiny, ked' sme sa všeobecne pýtali, či sa im hodiny páčili, alebo sa im zdali nudné, alebo či by nechceli robit' niečo iné. Všetci chceli pokračovat' v stavaní až na jedného žiaka, ktorý

\footnotetext{
${ }^{5}$ ktorý je možné si všimnút' aj v d’alej uvádzaných odpovediach žiakov
}

chcel íst' na počítač, lebo doma mali pokazený internet a nemohol si skontrolovat' e-mail.

Ďalší zaujímavý jav sme objavili pri analýze odpovedí v Metódel v poslednom stĺpci tabul'ky. $\mathrm{V}$ ňom sa nachádzal kolotoč, ktorý vyzeral ako mlyn a volal sa „Náš mlyn“. Všetci uviedli, že sa im páčil preto, lebo: „Vyzerá ako mlyn.“. Všetci žiaci zo skupiny uviedli rovnaký, podobne naformulovaný dôvod. Príčinu tohto javu nám čiastočne vysvetlila triedna pani učitel'ka (otázky č. 4 a 5). Je normálne, že žiaci v tomto veku často kopírujú vzory, ktoré vidia. Takže najtažšie to mal ten, kto vypín̆al tabul'ku ako prvý. V tomto prípade to bola Janka, ktorej napísané odpovede patrili ku kratším. Jej krátke vety, podl'a tvrdenia pani učitel'ky, neboli spôsobené slabším vyjadrovacím aparátom, ale práve tým, že prišla ako prvá a koncepciu viet musela vytvárat' sama. Triedna učitel'ka nám tiež vysvetlila, že výstižnost' a zložitost' odpovedí žiakov súvisia $s$ ich spôsobom vyjadrovania. Niektorí žiaci sú struční, presne a jasne sa vyjadrujúci ako napríklad Miriam a Milo. Miriamine vety boli najkratšie, ale výstižné. Ukážka jej štyroch odpovedí: „Páćil sa mi, lebo bol zábavný.“, „Tento som stavala ja a Janka.“, „Páčil sa mi, lebo sa pekne točil.“ a „Páčil sa mi, lebo vyzeral ako mlyn." Žiaci, ktorí sú komunikatívnejší, výreční, nemali problém napísat' viac textu napr. Danka. Podl'a skúsenosti pani učitel'ky však vo väčšine takýchto prípadov logické myslenie nie je až tak rozvinuté. Ukážka jednej Dankinej odpovede: „lebo mal pas lebo sa pekne točil lebo mali dobré nápady". Danka patrila do skupiny, kde sme použivali Metódu2. Ostatní žiaci uvádzali ovel'a kratšie odpovede, ako napríklad: „lebo bol bespečný", „lebo sa mohol zdvíhad"“, „LEBO VIZERAL AKO GULOMET.“, ... . Stručné odpovede v Metóde2 mohol spôsobit’ aj krátky čas, ktorý mali žiaci na vypracovanie zadania.

Týmto popisom charakteru žiakov nám pani učitel'ka odpovedala na otázku 6,7 a k otázkam 7, 8 a 9 sa vyjadrila nasledovne: Každý zo žiakov je jedinečný, každý má svoj vlastný charakter. Tom je napríklad diet’a, ktoré je vel'mi hyperaktívne, komunikatívne, po intelektuálnej stránke vel'mi rozvinuté a vel'mi dobre spolupracuje s kýmkol'vek. Tieto pozitívne a pre úspešnú spoluprácu dôležité vlastnosti si žiaci naozaj uvedomujú. Aj preto medzi najčastejšie odpovede žiakov, pri zdôvodnení otázky, prečo by chceli byt' nabudúce s niekým v tíme, patrili tieto zdôvodnenia: „lebo sú šikovni", „lebo dobre stavajü", "lebo dobre pracujü", „lebo sa mi 
dobre s nimi pacuje“, „lebo sú dobri". Jediná, výrazne odlišná odpoved' bola od Otílie, ktorá napísala, že by chcela byt' na d'alšej hodine sama. Jej zdôvodnenie znelo: „lebo ma nikto nediriguje“. Podl'a slov pani učitel'ky má problém pracovat's niekým, lebo má vel'mi dominantnú povahu. Žiaci $\mathrm{s}$ ňou nechcú byt' $\mathrm{v}$ tíme, lebo nechce pristúpit' na spoločné dohody a svoje názory si presadzuje niekedy aj fyzickým násilím. Spolužiaci sa naučili, že ak s ňou budú v tíme, nedostanú sa $\mathrm{k}$ slovu, ani sa nebudú môct' aktívne zapájat'. Tieto informácie nám objasnili dôvod, prečo žiaci neuvádzali Otíliu medzi žiakov, s ktorými by chceli byt' na d'alšej hodine $\mathrm{v}$ tíme. Môžeme teda vidiet', že žiaci vedia strategicky rozmýšl'at'o vhodnom výbere členov do svojich skupín.

Aby žiaci v takomto veku vedeli dopredu plánovat' a neboli ovplyvňovaní len práve zažívanou skutočnost'ou, alebo tým, kto je ich najlepší kamarát, musí byt' takéto myslenie rozvíjané. Pani učitel'ka nám naozaj potvrdila(otázky č.1, 2 a 3), že žiaci sú na ich škole od prvého roka vedení $\mathrm{k}$ tomu, aby sa dokázali samostatne vyjadrovat'. Učitelia sa preto do výučby počas celého školského roku snažia zakomponovat' také aktivity, ktoré by rozvíjali u žiakov takéto myslenie. Napríklad žiaci sú povinní už od prvého ročníka publikovat' do školského časopisu, písat' sebahodnotenie $\mathrm{k}$ vysvedčeniu a podobne. Podl'a vyjadrenia pani učitel'ky, implementované metódy hodnotenia nemali byt' pre žiakov intelektuálne náročné. Aktivity na vyjadrenie vlastného názoru ona sama vel'mi často používa ako metódu hodnotenia na hodinách, avšak skôr vo forme ústnej, ako písomnej. Žiakov vedie k tomu, aby sa nehanbili a povedali svoje názory a myšlienky. Aj to môže byt' jeden z dôvodov, prečo sa žiaci nepýtali učitel'ov, aké odpovede majú do tabul'ky písat'.

Podl'a osobného názoru pani učitel'ky, žiaci musia prejst' po viacerých stupienkoch $\mathrm{k}$ tomu, aby sa vedeli správne vyjadrovat' a takéto metódy hodnotenia sú jedným z nich.

\section{Diskusia a závery}

V článku sme opísali návrh a priebeh implementácie netradičných metód hodnotenia, o ktorých si myslíme, že rozvíjajú dôležité, ale často zanedbávané funkcie hodnotenia ako napr. motivačná, spätnoväzobná, rozvíjajúca a výchovná. Táto prípadová štúdia ukázala, že ak sú žiaci vedení k vytváraniu, formulovaniu a prezentovaniu svojich názorov už od prvého ročníka ZŠ, vedia sa $\mathrm{k}$ hodnoteniu a sebahodnoteniu postavit' vel'mi racionálne a prirodzene. Pri implementovaní nami navrhnutých netradičných metód hodnotenia, žiaci pracovali prirodzene a spontánne, ako ked' sme im zadávali úlohy na začiatku hodiny. Nestretli sme sa s nechápavými pohl'admi a otázkami žiakov, ktorými by žiadali presné inštrukcie na vypracovanie týchto zadaní. Žiaci použili mechanizmy a spôsoby riešenia, ku ktorým boli doteraz vedení. Problémy nenastali na úrovni obsahovej, ale výrazovej, kde žiaci nemali ešte úplne zvládnutú gramatiku jazyka.

Dôvody a argumenty, ktorými žiaci zdôvodňovali svoje rozhodnutia boli premyslené a založené na dlhodobej skúsenosti. Obsahovali prvky dlhodobého plánovania a strategického myslenia. Rozhovor s učitel'kou potvrdil, že takéto netradičné metódy hodnotenia majú miesto v školskej výučbe a prispievajú k čiastkovému napíňaniu ciel'ov pre rozvoj argumentačných schopností žiakov.

\section{Literatura}

[1] Atmatzidou, S. Markelis, I. Demetriadis, S. The use of LEGO Mindstorms in elementary and secondary education: game as a way of triggering learning. 2008, Workshop Proceedings of SIMPAR Intl. Conf. on SIMULATION, MODELING and PROGRAMMING for AUTONOMOUS ROBOTS, s. 22-30. Venice(Italy) 2008, ISBN 978-88-95872-01-8 (print).

[2] Dagdilelis, V. Sartatzemi, M. Kagani, K. Teaching (with) Robots in Secondary Schools: some new and not-so-new Pedagogical problems. 2005, ICALT'05 - Proceedings of the Fifth IEEE International Conference on Advanced Learning Technologies, s. 757-761. ISBN:0-7695-2338-2 (print).

[3] Hussain, S. Lindh, J. Shukur, G. The effect of LEGO Training on Pupils' School Performance in Mathematics, Problem Solving Ability and Attitude: Swedish Data. 2006.Educational Technology \& Society, s. 182-194. ISSN 14364522 (online) and 1176-3647 (print).

[4] LEGO ${ }^{\circledR}$ MINDSTORMS® ${ }^{\circledR}$ NXT 2.0. (online) [cit. 2012-12-14]. URL : <http://mindstorms.lego.com/enus/products/default.aspx $>$.

[5] DevTech Research Group. A Curiculum Unit on Programing and Robotics. (online) [cit. 201212-14]. URL http://api.ning.com/files/pTaEwxWbXOXEvuHU 
8f7N4KIH76oLjbiFnY23K28QpazleBAFGekTJ GOQME9VCBK31S8SQr4RkZVUw3PL-

3CYYnrIrbVgGgqF/WeDoThePlaygroundCurric Grades12.pdf>.

[6] GURA, M. Getting Started with LEGO Robotics. 2011, ISTE. ISBN 978-1-56484-298-5.

[7] Mayerová, K., Veselovská, M. Robotic kits and key competences in primary school. 2012, Information and Communication Technology in Education. Ostrava: University of Ostrava, Pedagogical Faculty, s. 175-183. ISBN 978-807464-135-0 (print).

1) [8] Švaříček, R., Šed'ová K. a kol. Kvalitativní výzkum v pedagogických vedách. 2007.

In: Praha: Portál, s. r. o., 384 str. 1. vyd. ISBN 978-80-7367-313-0(print).

[9] Rocha Neves, O. Mota Alves, J. Ramos J. An 8 Year Old Educational Robotics Program Structure, Methodology and Goals. 2011, D. Obdržálek and A. Gottscheber: EUROBOT 2011 , s. 236-247. 1. vyd. ISBN 978-3-642-21975-7 (print).
II. [10] Marais, A. Smith, A. Duvejkog, N. TekkiKids: Experiences in implementing technology clubs in a South African context. 2008, 3rd International Conference on ELearning: Icel, s. 273-282. ISBN 978-1-90663804-7 (print).

[11] KALHOUS, Z., OBST, O. a kol. Školní didaktika. 2009, Praha: Portál, s. 447. 2. vyd. ISBN 978-80-7367-571-4 (print).

[12] Turek, I. Didaktika. 2008, Bratislava: IURA EDITION. 1. Vyd. ISBN 978-80-8078.198-9 (print).

Mgr. Karolína Mayerová, Mgr. Michaela Veselovská, Katedra základov a vyučovania informatiky Fakulta matematiky, fyziky a informatiky UK Mlynská dolina

842 48, Bratislava, SR

E-mail: mayerova@fmph.uniba.sk veselovska@fmph.uniba.sk

Www pracovisko:

http://www.edi.fmph.uniba.sk 